\title{
The Effect of Self-Care Training for Health Ambassadors on The Number of Doctor Appointment Due to The Treatment of Minor Ailments
}

\begin{abstract}
Background and Objective: The aim of this study was to investigate the effect of self-care training for family health ambassadors on the number of doctor appointment for the treatment of minor ailments.

Materials and Methods: In this interventional study were surveyed 400 families. This study was performed in 2018-2019.The intervention group included families that had a health ambassador and the intervention was performed for health ambassadors. Data collection tool was a questionnaire designed by the Office of Education and Health Promotion of the Ministry of Health. Demographic information and the number of appointments to the doctor were also asked. According to the titles of the educational text and the family age groups, trainings were provided to health ambassadors once every 2 weeks for a year. Total of 24 training sessions were held by the health care providers of the selected health centers. The questionnaires were completed, one year after the intervention again. Results: Mean and standard deviation of test scores in the experimental group were upgraded before and after the intervention in the field of mothers and infants from $5( \pm 2.9)$ to $22( \pm 7.1)$, children from $5.7( \pm 14.1)$ to $19.6( \pm 6.6)$, adults and the elderly were from $2( \pm 1)$ to $9.4( \pm 2.9)$ and adolescents from 2.1 $( \pm 1.80)$.Also, the number of appointments to the doctor due to minor illnesses decreased significantly in the intervention group during the year, so that from 888 appointments to the doctor by family members of trained health ambassadors before the intervention was reduced to 379 times after the intervention. $(p<0.05)$. Conclusion: Continuous self-care training along with following up and training family health ambassadors play an important role in increasing public awareness and reducing the number of unnecessary appointments to the doctor.

Keywords: Health ambassadors, Self-care, Minor ailments, Education, Reduce appointment to the doctor.

Paper Type: Research Article.
\end{abstract}

Citation (Vancouver): Shakiba E, Shahabadi S, Marzban B, Barkhordar Pooreayvazi N. The Effect of Self-Care Training for Health Ambassadors on The Number of Doctor Appointment Due to The Treatment of Minor Ailments. Iran J Health Educ Health Promot. Spring 2021;9(1): 68-79. [Persian]

C Citation (APA): Shakiba E., Shahabadi S., Marzban B., Barkhordar Pooreayvazi $N$. The Effect of Self-Care Training for Health Ambassadors on The Number of Doctor Appointment Due to The Treatment of Minor Ailments. Iranian Journal of Health Education \& Health Promotion., 9(1), 68-79. [Persian]

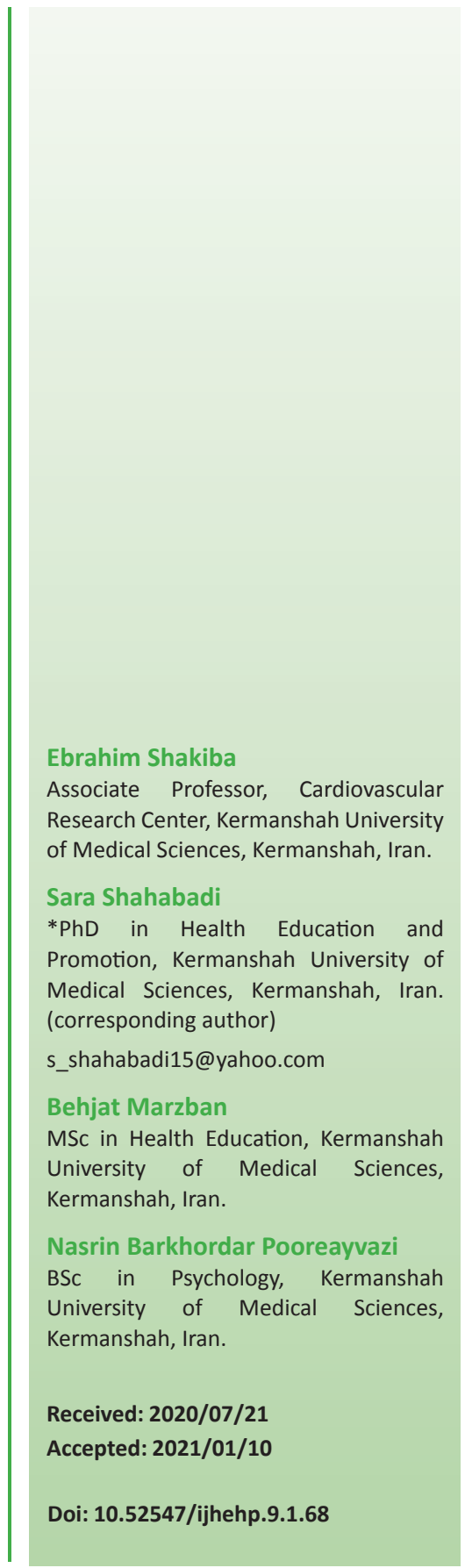




\section{تأثير آموزش خودمراقبتى به سفيران سلامت در ميزان مراجعه به يزشك براى

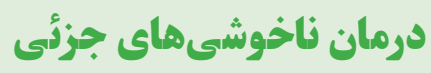

ابر اهيم شكيبا

دانشيار كروه بيوشيمى بالينى، مركز تحقيقات قلب

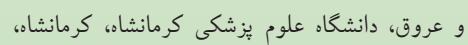

ايران.

سارا شاه آبادى إنى * دكترى تخصصى آموزش بهداشت و ارتقاى سلامت،

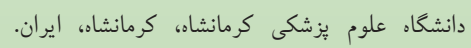
(نو يسنده مسئول)

\section{s_shahabadi15@yahoo.com}

بهابت مرزبانى كارشناس ارشد آموزش بهداشت و ارتقاى سلامت،

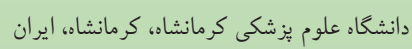

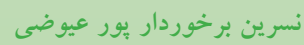

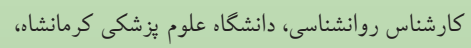

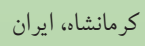

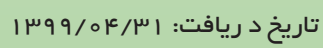

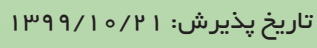

\section{-}

زمينه و هدف : هدف از اين مطالعه بر رسى ميزان تأثير آموزش خودمبر اقبتى به سفيران سلامت خانوار در

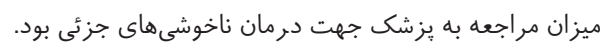

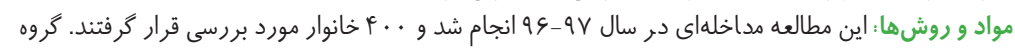

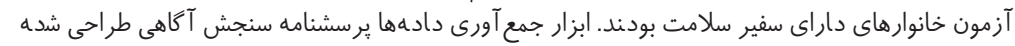

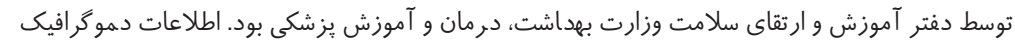

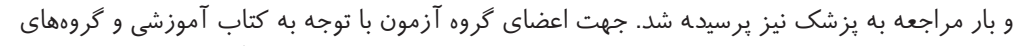

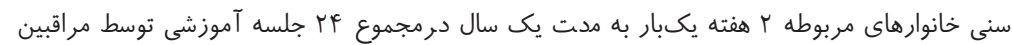

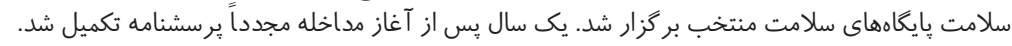

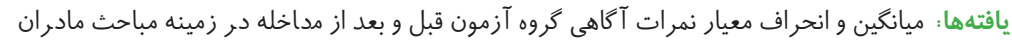
و نوزادان از (I/ )

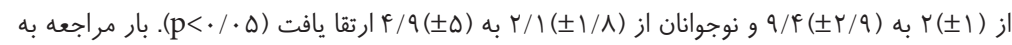

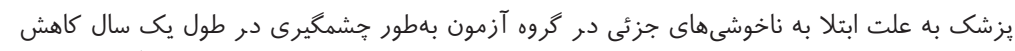

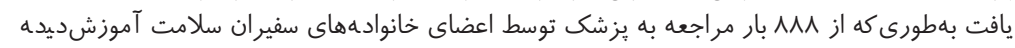
قبل از آزمون به و

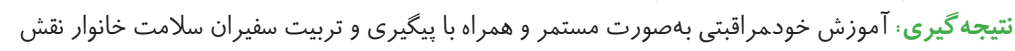

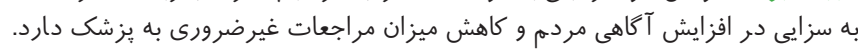

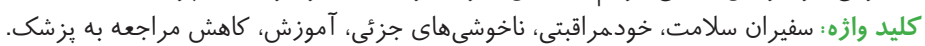

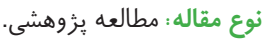

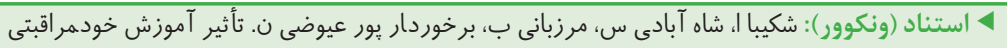

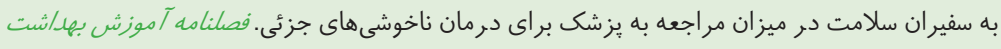

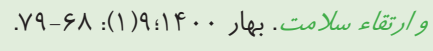

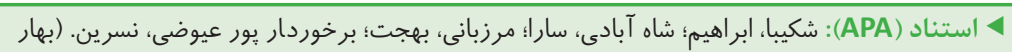

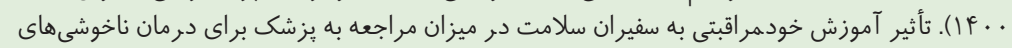

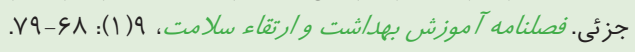


كنترل بيشترى بر وضعيت سلامت خود داشته باشند( (). خودمر اقبتى

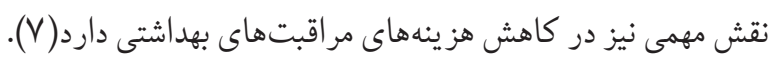

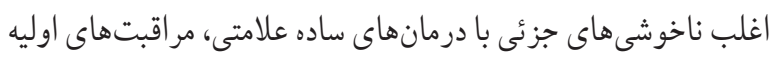

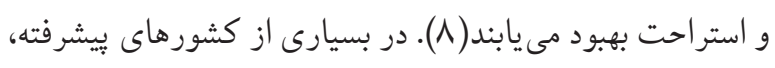

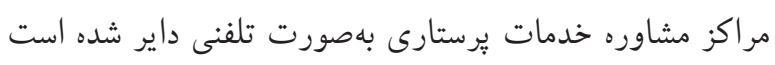
و خدمات مشاورهاى باكيفيت براى درمان اين ناخوشىها ارائه

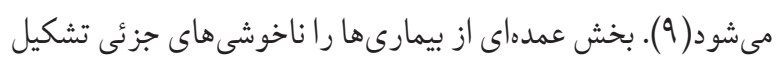

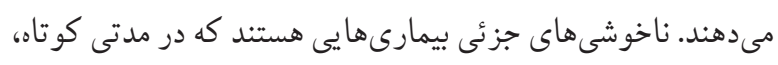

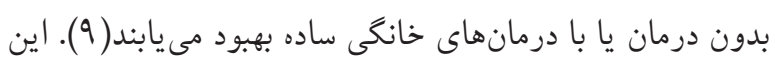

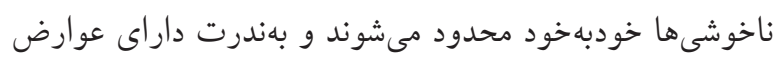

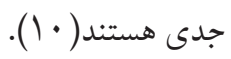

مطالعهاى در انكلستان نشان داد كه حدود • ب درصد از مراجعات

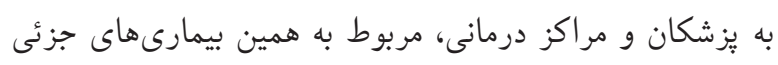

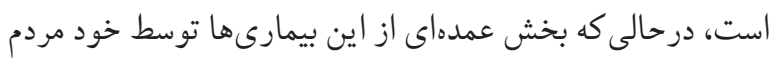

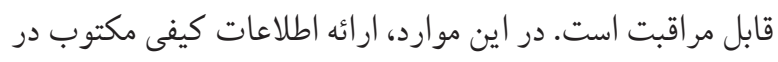

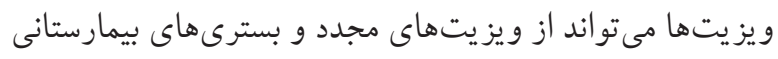

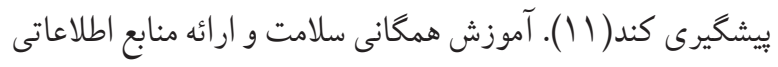

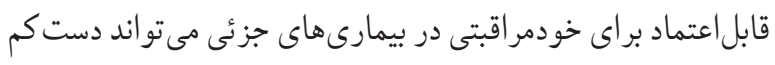

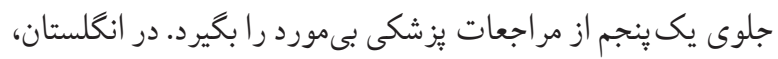

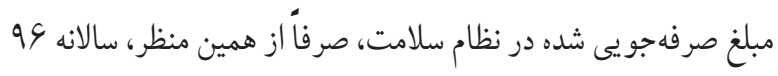

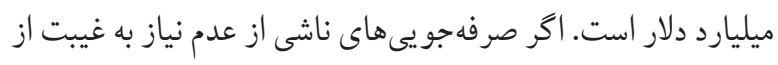

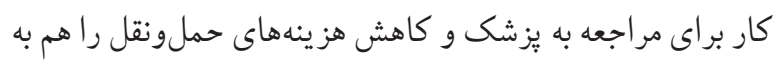

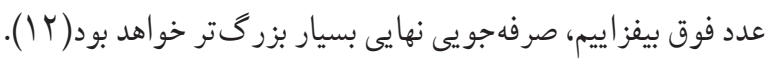

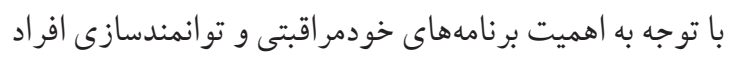

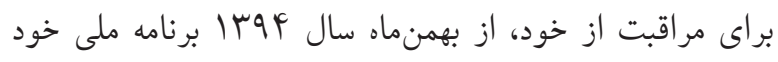

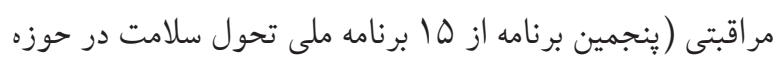

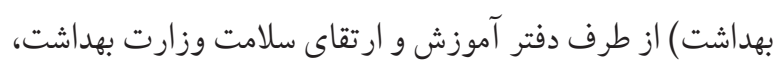

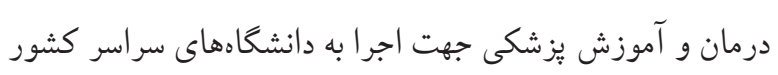

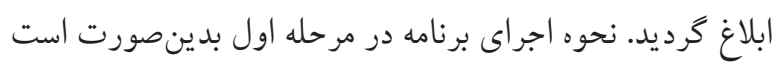

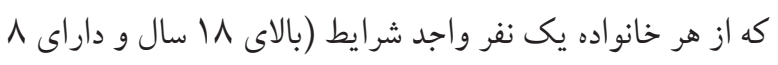

سازمان بهداشت جهانى، خودمراقبتى را بهعنوان "توانايى افراد، خانوادهها و جوامع در ارتقاء سلامت، جلوكيرى از بيمارى، حفظ

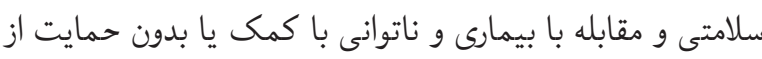

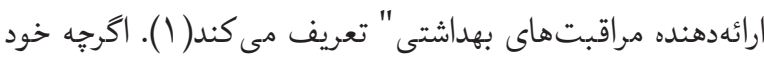

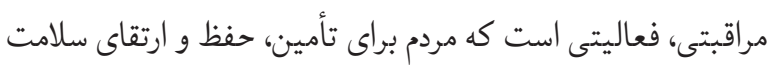

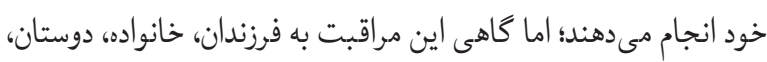

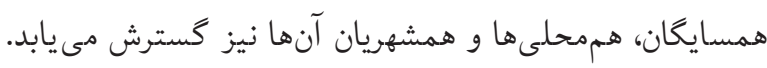

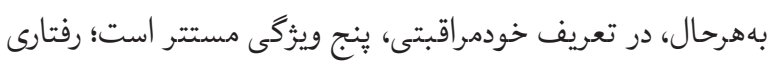

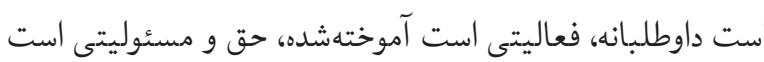

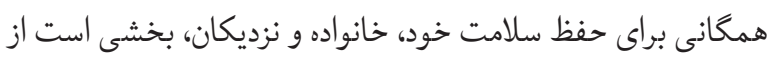

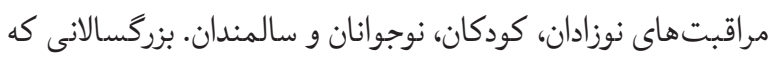

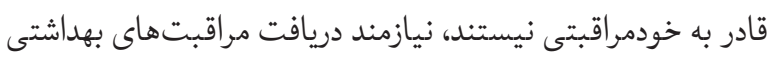

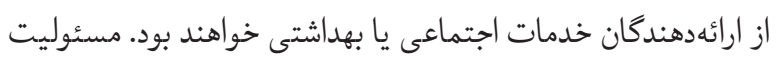

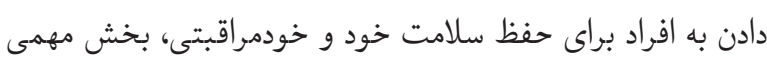

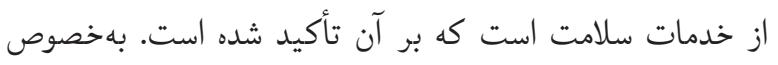

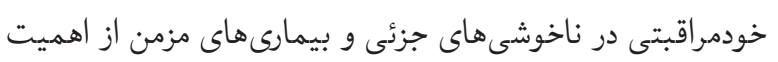

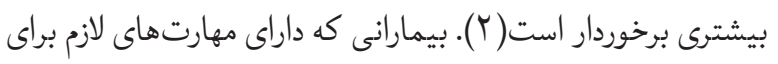
مراقبت از خودشان هستند كنترل بيشترى بر سلامتى خود دارند و نتايج بهترى در درمان بيمارى خود مي گيرند (باو \&).

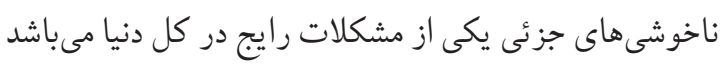

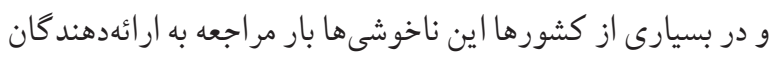

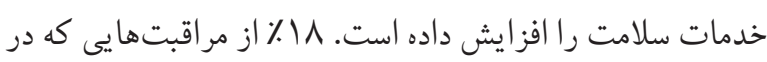

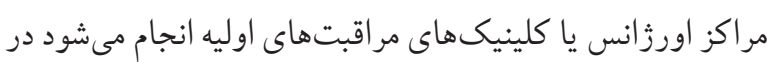

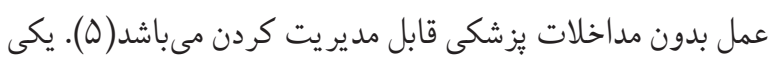

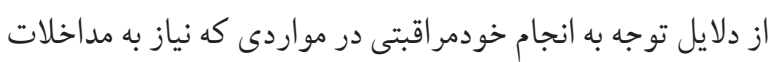

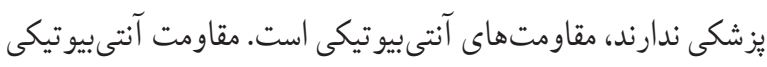

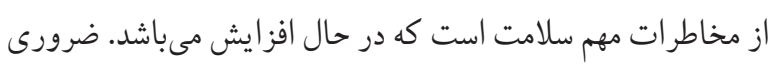

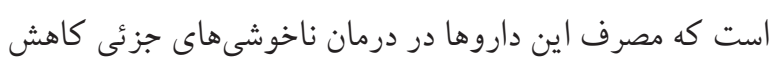

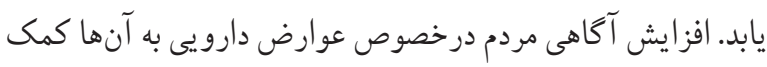

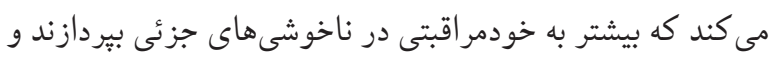




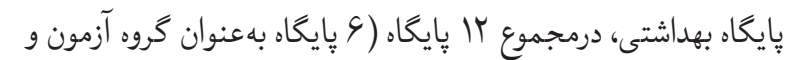

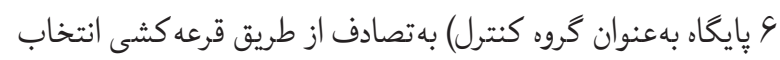

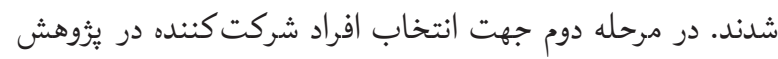

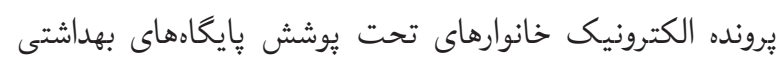
بهصورت تصادفى سيستماتيك موردبررسى قرار كرفت(نمودار ()). حداقل حجم نمونه مو ردنياز نيز براى اين مرحله از مطالعه با استفاده

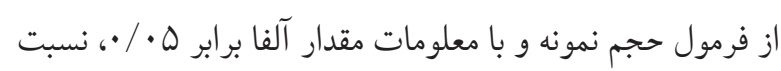

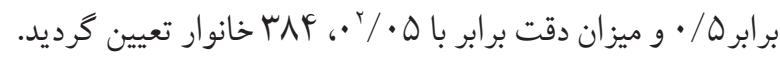

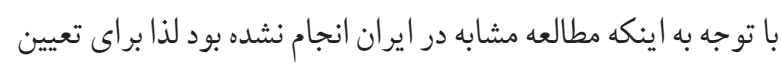

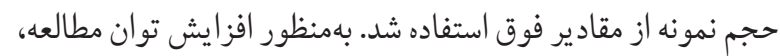

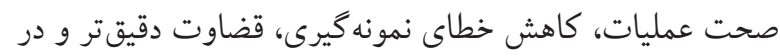
نظر كرفتن ها درصد ريزش، حجم نمونه . ㄷ خانوار تعيين كرديد.

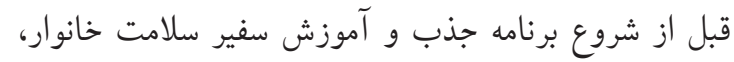

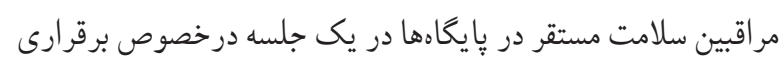

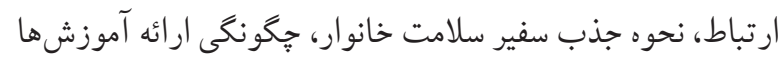

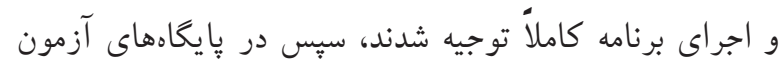

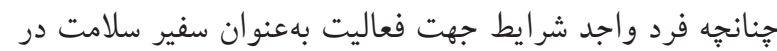

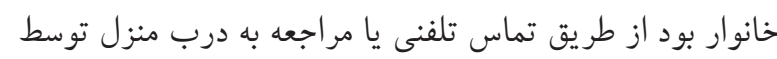

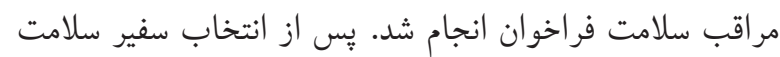

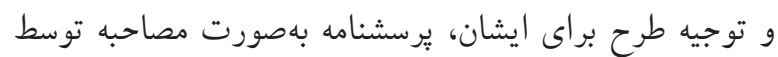
مراقب سلامت يا خوداظهارى توسط سفير سلامت تكميل گرديد.

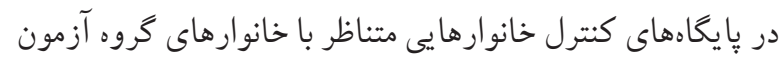

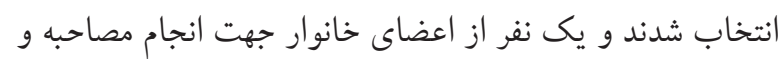

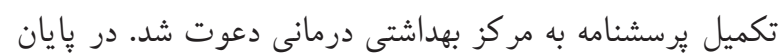

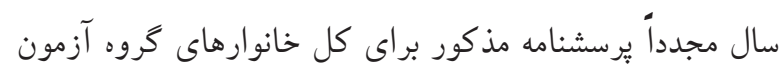

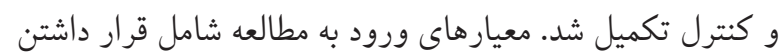

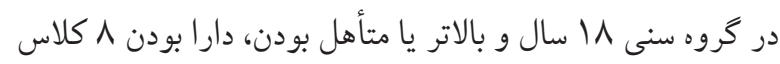

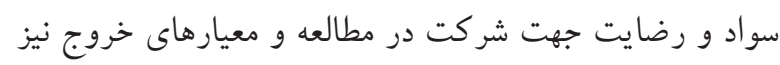

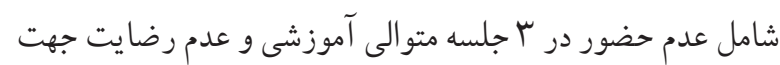
شر كت در مطالعه بود.
كلاس سواد خو اندن و نوشتن) بهعنوان سفير سلامت خانواده انتخاب

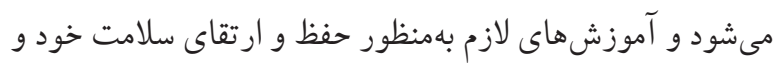

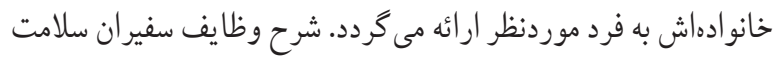
عبارت است: از كذراندن دورههاى آموزشى خودمراقبتى، انتقال

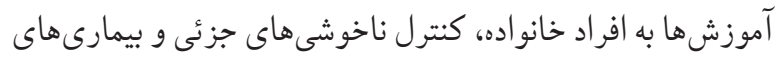

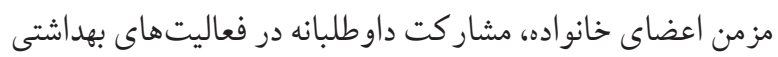
كروهى و جمعى و عضو يت در تشكلهاى مردمى حامى سلامت.

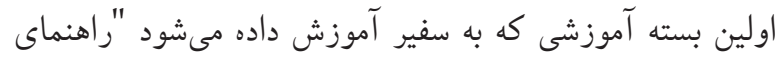

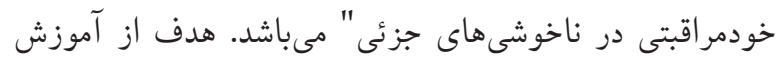

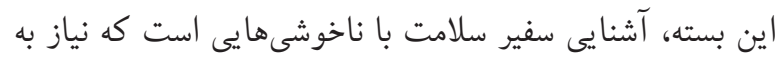

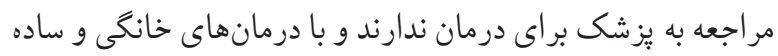

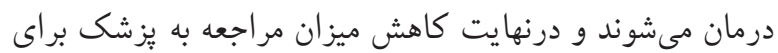
ناخوشىهاى جزئى مى باشد. با توجه به اينكه اين برنامه در كشور

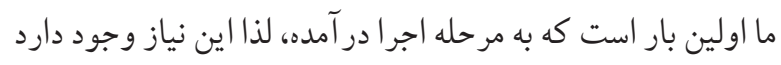
كه با استفاده از روش علمى ميزان اثربخشى اين برنامه سنجيده شود.

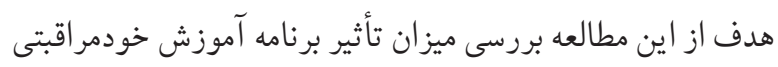

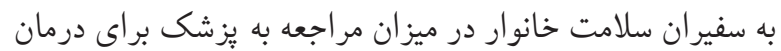

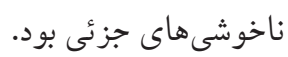

$$
\text { مو اد و روش ها }
$$
اين مطالعه مداخلهاى از نوع تصادفى سازى شده بود كه در خانوارهاى

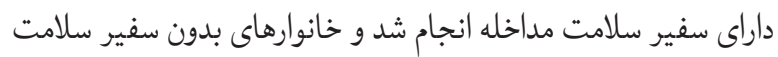
بهعنوان گروه كنترل مدنظر قرار گرفتند. مدتزمان انجام مطالعه به ماته

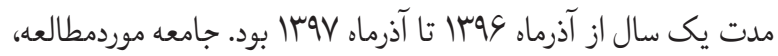
خانوارهايى بودند كه داراى برونده فعال در بايخاههاى بهداشت شهرى

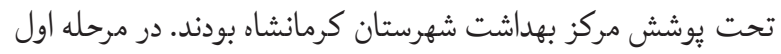

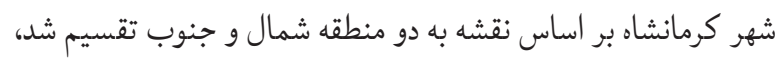

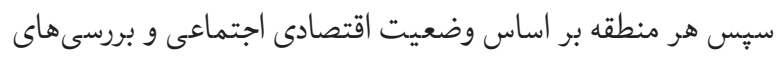
صورت گرفته توسط مركز بهداشت شهرستان كرمانشاه به ب ناحيه برخوردار، نيمه برخوردار و ضعيف تقسيم گرديد. از هر ناحيه دو 


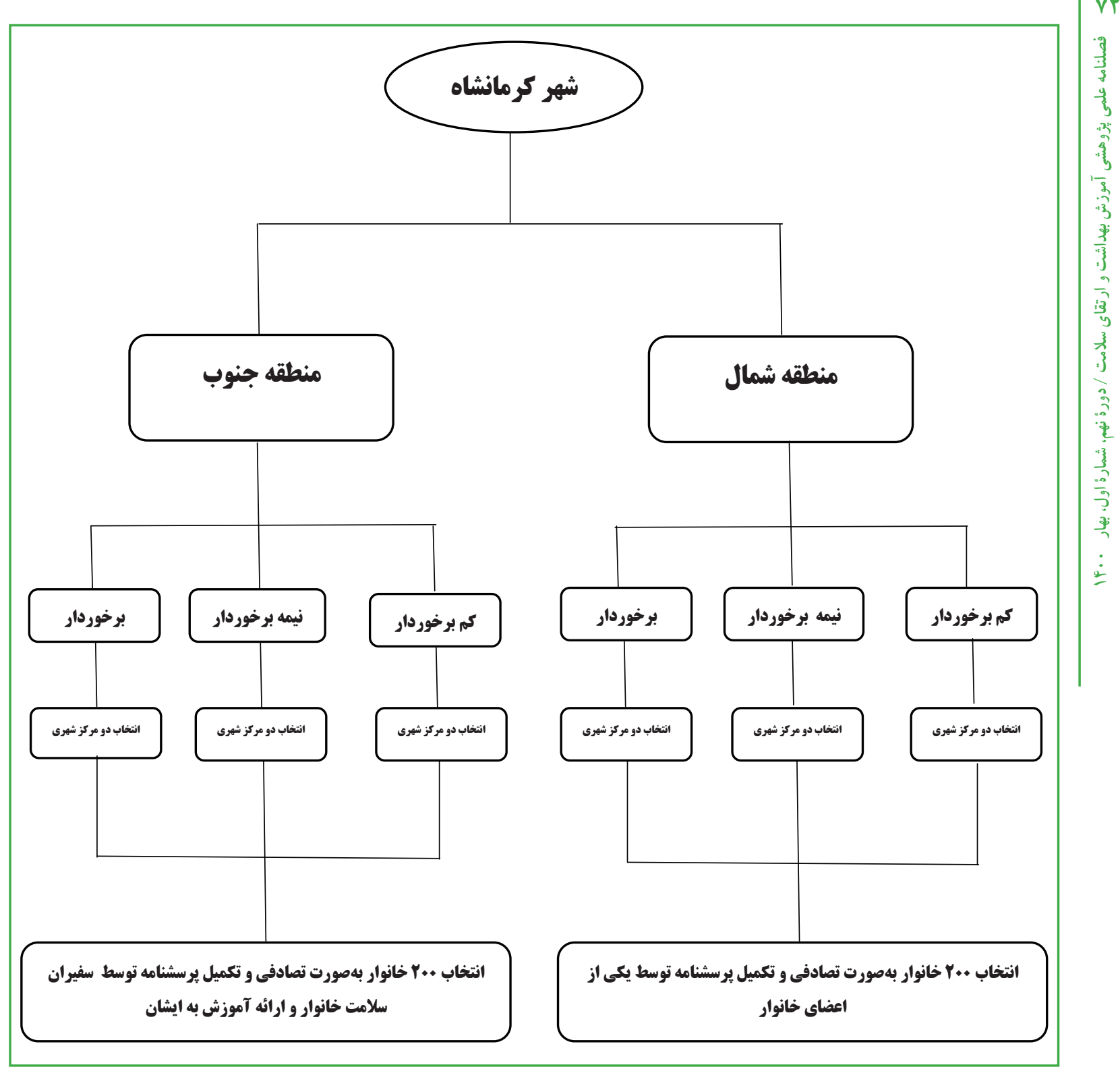

نمودار ا. نحوه انتخاب يايغاههاى سلامت و افراد شركت كننده در مطالعه

ابزار گردآورى دادهها

ابزار جمع آورى دادها يرسشنامهاى بود كه از سه بخش تشكيل شده سنى كه در خانوارها زندكى مى كنند آكاهى سنجى سفير سلامت انجام

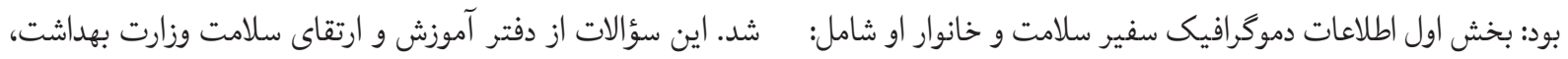

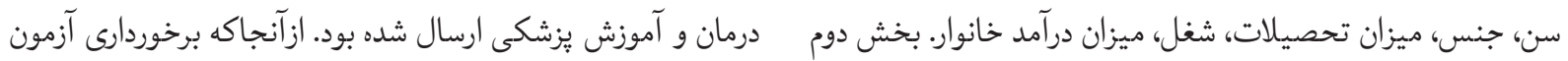

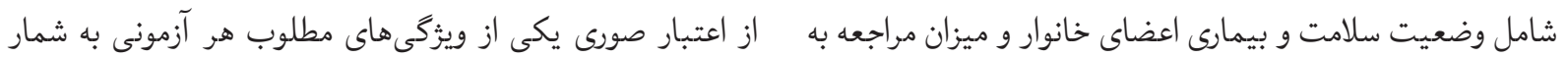

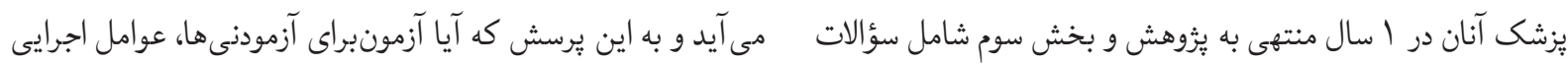

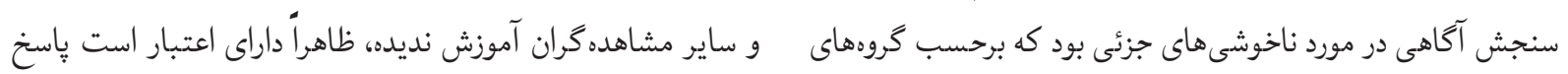


در خانوار زندگى مى كردند (نوزاد، كودى، مادر باردار و....) براى سفير

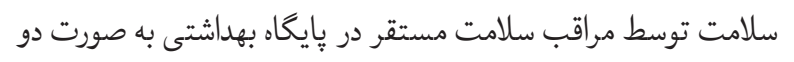

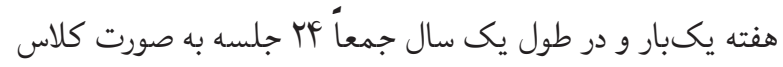
آموزشى و يرسش و پِاسخ بركزار شد. مدتزمان هر جلسه حداكثر ها دقيقه بود. همجنين در فضاى مجازى گروههاى آموزشى با حضور

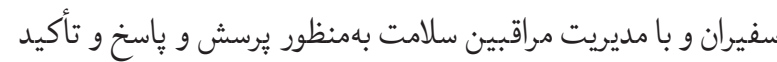
بر نكات مهم تشكيل گرديد. اهم مطالبى كه به سفيران آموزش داده

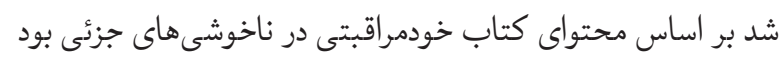

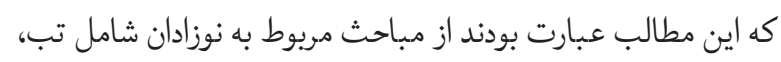

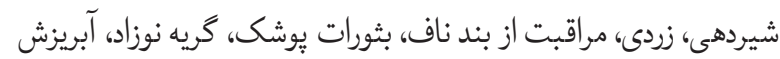

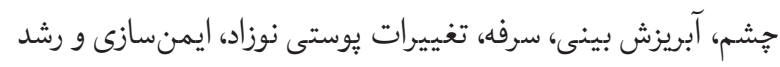

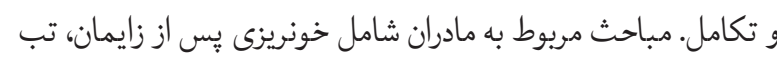

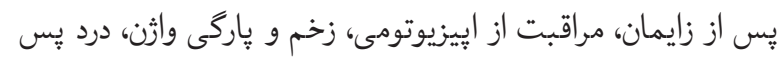

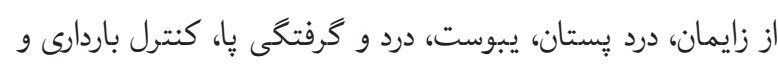

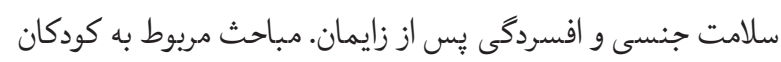

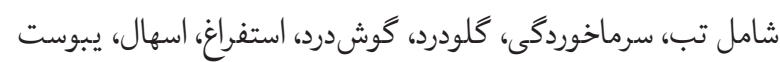
و آموزش دستشويى رفتن. مباحث مربوط به نوجوانان شامل آكنه و

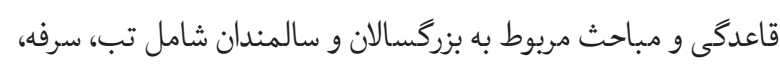

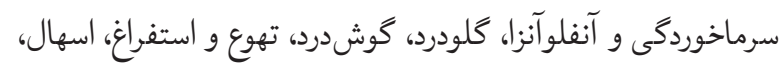
يبوست، مشكلات دفع ادرار و اختلالات جنسى. آناليز دادهها تجزيهوتحليل دادههاى مرتبط با استفاده از نرم|فزار SPSS16 انجام كرديد. براى توصيف جمعيت مورد مطالعه و كروه آزمون و كنترل

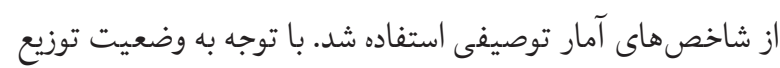

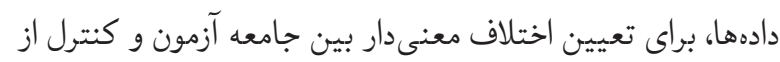

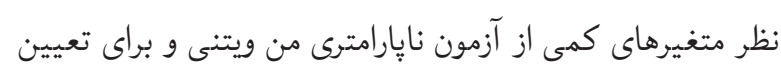

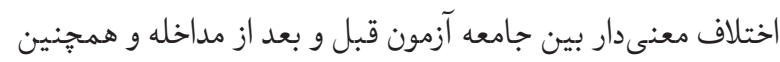

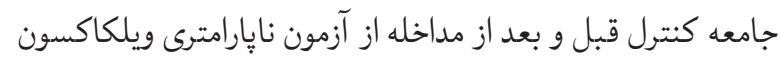
استفاده كرديد. همجنين براى متغيرهاى كيفى از آزمون كاى دو

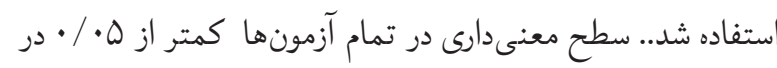
نظر كرفته شد.
مى دهد، لذا بهمنظور تعيين روايى صورى، برسشنامههاى تهيه شده

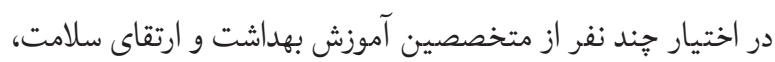

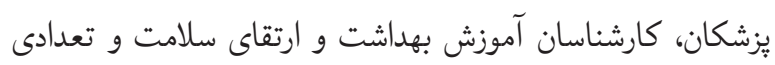

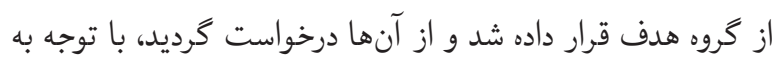
هدف يزوهش نظر خود را در مورد وضوح عبارات به كاربرده شده و ظاهر بِرسشنامه بهصورت كاملاً مناسب، مناسب و نامناسب، اعلام

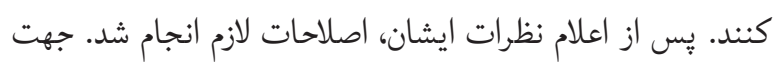

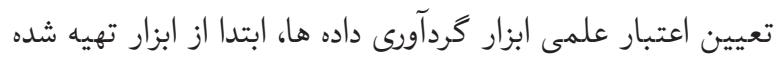

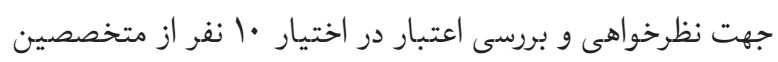
آموزش بهداشت و ارتقاى سلامت و يزشكان عمومى قرار كرفت. يس از دريافت نظرات، اصلاحات لازم با نظر اين متخصصين انجام

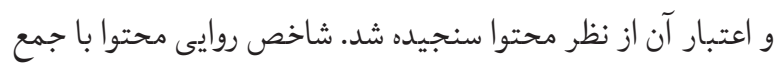

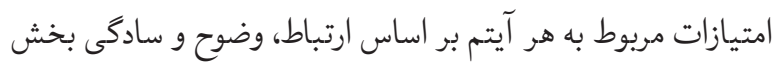
بر تعداد كل متخصصان محاسبه شد و عدد •^/ • به دست آمد.

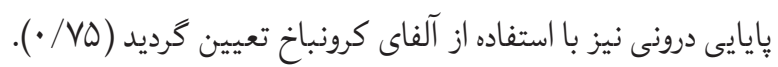

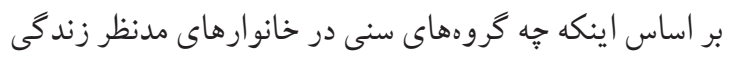

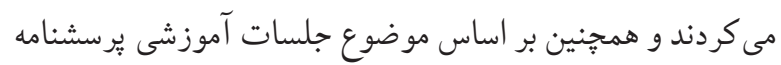

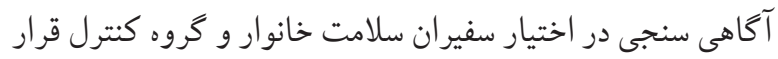

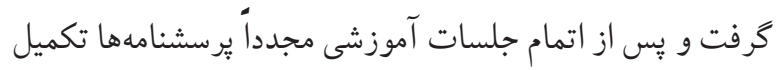

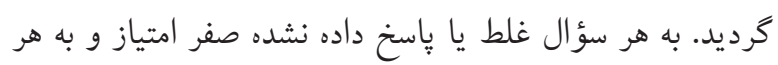

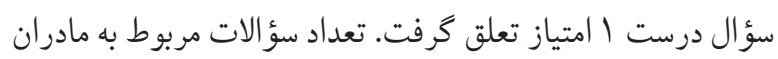

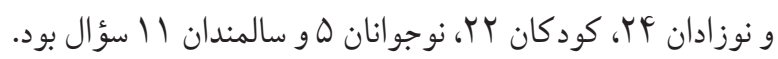
در بخش ميزان مراجعه به يزشك جهت درمان ناخوشىهاى جزئى، براى ييشخيرى از خطاى يادآورى فرصت كافى به افراد

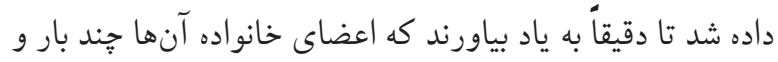

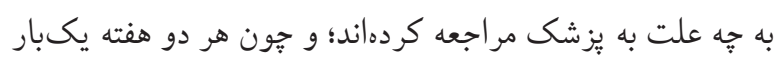

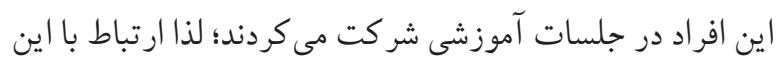

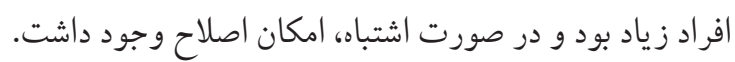

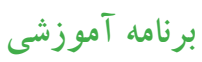
در ابتدا كتاب آموزشى خودمراقبتى در ناخوشى هاى جزئى در اختيار

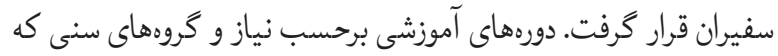


كردند. از نظر جنسيت، در گروه آزمون 9 جو درصد (MM نفر) و در اساس آزمون آمارى كاى دو اختلاف معنىدار ازنظر تركيب جنسيتى دردي

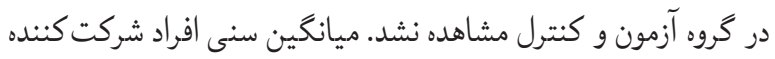
در كروه آزمون (II (I) سال بود. از نظر آمارى بين سن و مشخصات دموگرافيك از قبيل

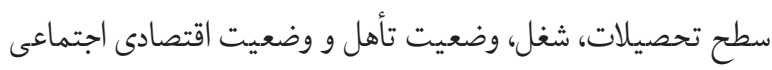

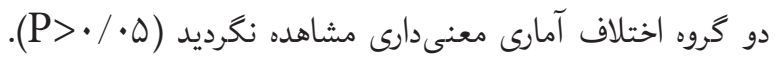

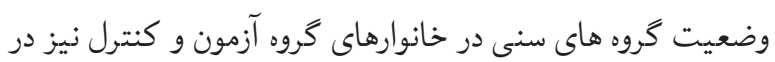

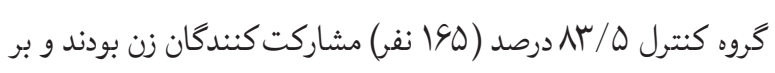

در اين يزوهش سعى شد كه نكات اخلاقى بدين شرح موردتوجه

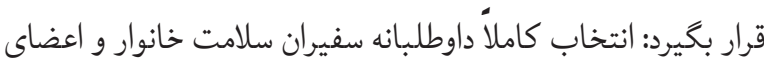
كروه كنترل، توجيه كامل اهداف طرح براى سفيران سلامت و گرووه كنترل، اخذ رضايتنامه كتبى براى شركت در طرح، در اختيار قرار

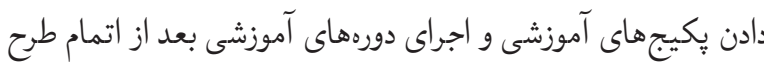

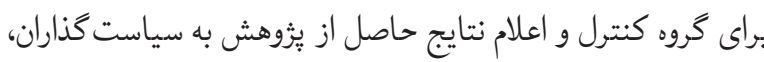
مديران و برنامه ريزان ذى بريط. يافتهاهـا در هريك از كروههاى آزمون و كنترل ..P نفر در مطالعه شركت

جدول ا. وضعيت كَروهاى سنى هدف خانوارها در كَروه آزمون و كنترل

\begin{tabular}{|c|c|c|c|c|c|}
\hline \multirow{2}{*}{ *P Value } & \multicolumn{2}{|c|}{ كروه كنترل } & \multicolumn{2}{|c|}{ كروه آزمون } & \multirow{2}{*}{ كروههاى سنى هدف } \\
\hline & درصد & فراوانى & درصد & فراوانى & \\
\hline \multirow{7}{*}{$\cdot / 9$} & $\cdot / \cdot \Delta$ & r & .19 & 4 & نوزاد از بدو تولد تا يك ماه \\
\hline & $\cdot / \mu$ & r & $\cdot 19$ & 4 & مادر, تازه زايمان كرده \\
\hline & rN/l & IV. & rᄉ & 1919 - (19) & كودكان يك ماه تا ب ا سال \\
\hline & $1 \cdot / 1$ & 41 & $\Lambda / r$ & $\Delta V$ & 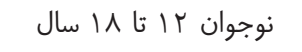 \\
\hline & $\Delta V / r$ & mfs & $\Delta V / s$ & mq1 & بزر گسال 19 تا •.4 سال \\
\hline & r/入 & r מ & $p / f$ & ו & فرد • سال به بالا \\
\hline & $1 \ldots$ & $s \cdot \Delta$ & $1 \ldots$ & 991 & جمع \\
\hline
\end{tabular}

بر اساس نتايج بهدست آمده به جز آكاهى در مورد مسائل مربوط بود( جدول شماره Y).

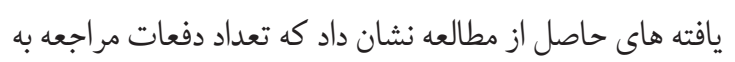

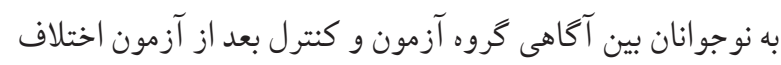

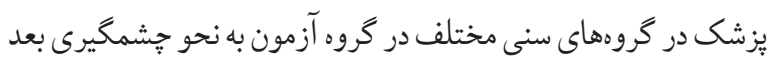

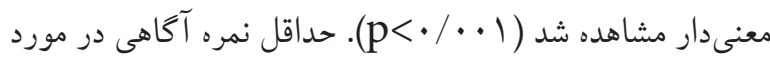

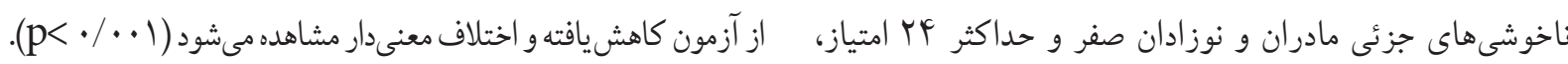

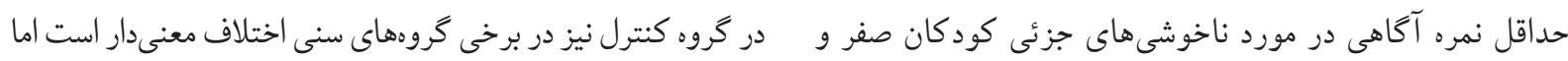

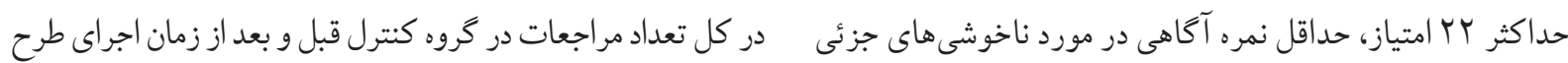

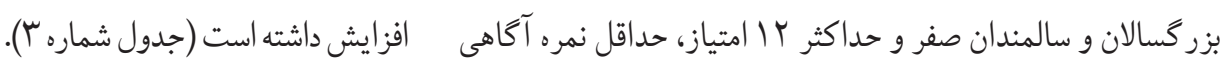
در مورد ناخوشىهاى جزئى در نوجوانان صفر و حداكثر ها امتياز 
جدول r. مقايسه ميانگين و انحراف معيار ميزان آكَاهى دو گَروه آزمون و كنترل قبل و بعد از مداخله

\begin{tabular}{|c|c|c|c|c|}
\hline \multirow{2}{*}{$* *$ P Value } & بعد از مداخله & قبل از مداخله & \multirow{2}{*}{ 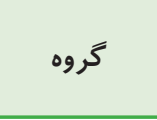 } & \multirow{2}{*}{ متغير ها } \\
\hline & ميانگين (انحراف معيار) & ميانگين (انحراف معيار) & & \\
\hline$<\cdot / \cdots 1$ & $r Y(V / I)$ & $\Delta(r / 9)$ & آآمون & \multirow{3}{*}{ مادران و نوزادان } \\
\hline \multirow[t]{2}{*}{$<\cdot / \cdots 1$} & $9 / 9(\Lambda / F)$ & $\Delta / V(r / F)$ & كنترل & \\
\hline & $<\cdot 1 \cdot \cdot 1$ & .10 & * P Value & \\
\hline$<\cdot / \cdots 1$ & $10(8 / 9)$ & $\Delta / V(r / l)$ & 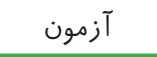 & \multirow{3}{*}{ كودكان } \\
\hline \multirow[t]{2}{*}{$\cdot / \cdot \mu$} & $\wedge(\Delta / 9)$ & $\Delta / \mathcal{F}(\Psi / 1)$ & 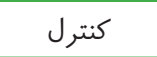 & \\
\hline & 米米籼 $>1.1$ & .19 & * P Value & \\
\hline$<\cdot / \cdot \cdot 1$ & $q / F(r / q)$ & $r(1 / r)$ & 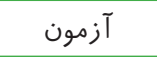 & \multirow{3}{*}{ بزر گسالان و سالمندان } \\
\hline \multirow[t]{2}{*}{$\cdot / \cdot r$} & $V / Y(Y / q)$ & $\Delta(r / \mu)$ & 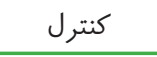 & \\
\hline & 米料水 $1 \ldots 1$ & $\cdot 14$ & * P Value & \\
\hline$<\cdot / \cdots 1$ & $r / q(r / \mu)$ & $r / I(1 / \Lambda)$ & 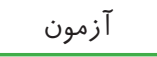 & \multirow{3}{*}{ 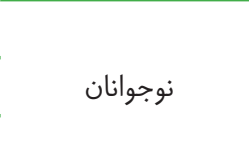 } \\
\hline \multirow[t]{2}{*}{$\cdot / 0$} & $r / r(I / \Delta)$ & $r / r(I / V)$ & كنترل & \\
\hline & $\cdot / \mu$ & $\cdot 10$ & * P Value & \\
\hline
\end{tabular}

جدول س. مقايسه وضعيت ميزان مراجعه به يزشك به علت ابتلا به ناخوشىهاى جزئى در گروه آزمون و كنترل قبل و بعد از مداخله

\begin{tabular}{|c|c|c|c|c|}
\hline * P Value & تعداد دفعات مراجعه به بعد از مداخله & تعداد دفعات مراجعه به & & كروه سنى \\
\hline$<\cdot / \cdot \cdot 1$ & . & 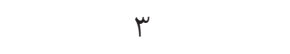 & آز & \multirow{2}{*}{ نوزاد از بدو تولد تا يك ماه - } \\
\hline$<\cdot / \cdots 1$ & . & 4 & كنترل & \\
\hline$<\cdot / \cdot \cdot 1$ & If & r & آزمون & \multirow{2}{*}{ مادر, تازه زايمان كرده } \\
\hline$<\cdot / \cdots 1$ & . & 19 & كنترل & \\
\hline$<\cdot / \cdots 1$ & $r \|$ & $\Delta \cdot r$ & آزمون & \multirow{2}{*}{ كودكان يك ماه تا Y I سال - } \\
\hline$\cdot / V$ & 149 & 110 & كنترل & \\
\hline$<\cdot 1 \cdot \cdot 1$ & $r v$ & 09 & آزمون & \multirow{2}{*}{ نوجوان r | تا \1 سال } \\
\hline$\cdot / \mu$ & rt & rq & 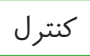 & \\
\hline$<\cdot / \cdots 1$ & 91 & rsG & 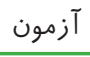 & \multirow{2}{*}{ بزرگسال 19 تا • ع سال } \\
\hline$<\cdot / \cdot \cdot 1$ & 189 & $I S F$ & كنترل & \\
\hline$<\cdot / \cdot \cdot 1$ & 11 & $\Delta r$ & آزمون & \multirow{2}{*}{ فرد · ع سال به بالا } \\
\hline$\cdot / r$ & 01 & qq & كنترل & \\
\hline$<\cdot 1 \cdot \cdot 1$ & msl & $\Lambda \wedge$ & آزمون & \multirow{2}{*}{ جمع } \\
\hline.$/ 1$ & "N1 & rva & كنترل & \\
\hline
\end{tabular}


خانوادهها را بر عهده دارند، لذا بهترين كزينه براى اين نوع فعاليتها هستند و همان كونه كه در اين مطالعه مشاهده شد اين افراد تمايل

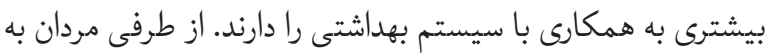
دليل مشغلههاى كارى فرصت كافى جهت برداختن به اين مسائل را ندارند يُ بهترين كزينه براى فعاليت بهعنوان سفيران سلامت خانوار

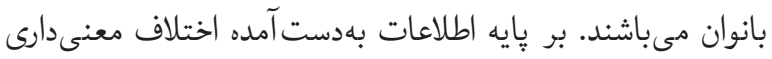

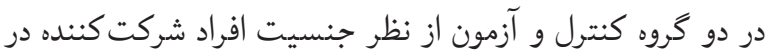
طرح وجود نداشت هرجند همان گونه كه اشاره شد در هر دو گروه تره تعداد زنان بسيار بيشتر از مردان بود. بر اساس يافتههاى حاصل

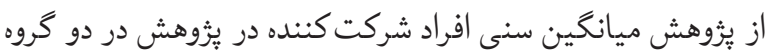
آزمون و كنترل نيز تفاوت معنى دار نشان نداد. مطابق با دستور العمل كشورى برنامه ملى خودمر اقبتى حداقل

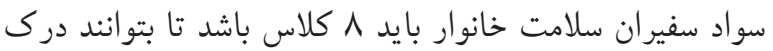
درستى از مطالب درجشده در كتب آموزشى داشته باشند. در اين

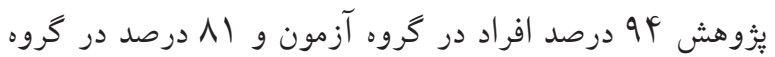
كنترل داراى مدرك سيكل و بالاتر بودند و از نظر سطح سواد، شركت كنند كان در مطالعه شايستكى لازم را مطابق با بروت مدكل كشورى دارا بودند. در اين بزوهش افر اد شركت كننده از نظر شغل

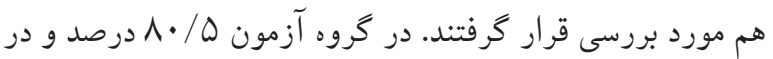
كروه كنترل ه/99 درصد مشار كت كنند مان در مطالعه خانهدار بودند. با توجه به اهميت داشتن زمان كافى جهت مدير يت سلامت خانواده و شر كت در كلاسهاى مستمر آموزشى، اين مسئله نيز تا حدودى از نقاط قوت اجراى طرح بهحساب مى آمد.

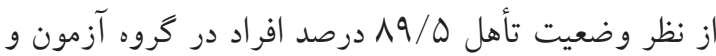

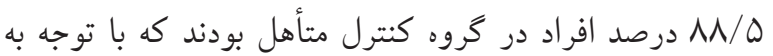
مسئوليت پِيرتر بودن افراد متأهل و تسلط ايشان در مديريت

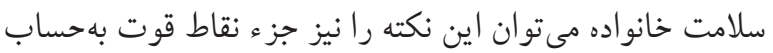

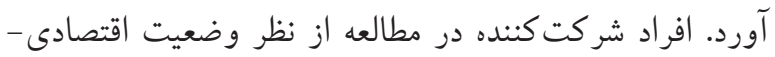
اجتماعى بر اساس محل سكونت نيز مورد بررسى قرار گرفتند.

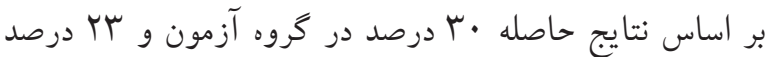

هدف از اين مطالعه بررسى ميزان تأثير آموزش خودمراقبتى به سفيران سلامت خانوار در ميزان مراجعه به بزشك جهت درمان ناخوشىهاى

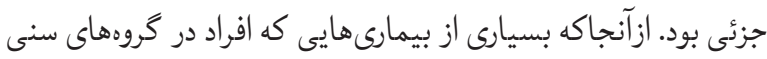

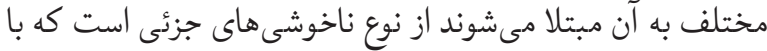

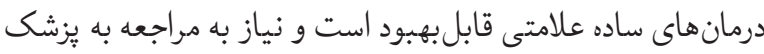
ندارد، لذا اين طرح به تأثير آموزش خودمراقبتى دانى در ناخوشىهاى جزئى بر اساس سرفصلهاى كتاب منتشرشده توسط وزارت بهداشت، درمان و آموزش بزشكى (كروه آموزش و ارتقاى سلامت) به سفيران سلامت خانوارهاى تحت مطالعه يٍرداخت. هرجند كه اين برنامه در

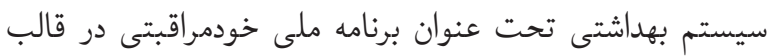
برنامه خودمراقبتى فردى در حال اجرا مى باشد؛ اما به دليل تراكم كارى مراقبين سلامت و بهورزان، كمبود منابع مالى جهت تهيه كتب آموزشى مرتبط و عدم تمايل و همكارى مردم در برخى از نقاط استان برنامه مذكور با دقت و بهدرستى انجام نمى شود و استانداردهاى لازم

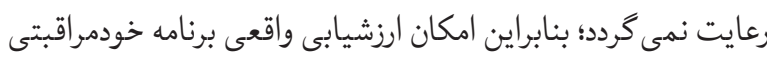
فردى كه ركن اصلى آن تربيت سفيران سلامت خانوار و آموزش عميق برديق به آنان است وجود ندارد. در اين يُوهش سعى شد كد كه استانداردهاى برنامه مطابق دستورالعمل هاى كشورى و با دقت لازم رعايت شود

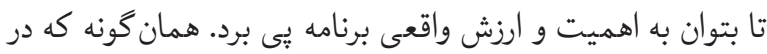

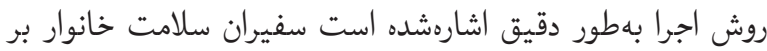
اساس گروههاى سنى كه با اين افراد زندگى مى كردند و بر پايه سرفصلهاى موجود در كتاب خودمراقبتى در ناخوشىهاى جزئى

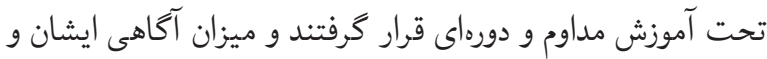
بار مراجعه به يزشك به علت ناخوشى هاى جزئى قبل و بعد از آزمون

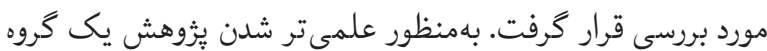
كنترل نيز در نظر گرفته شد كه تحت عنوان سفير سلامت خانوار نبودند و فقط يُرسشنامههاى مربوطه قبل و بعد از مدتزمان اجراى

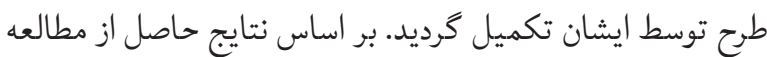
اكثر افرادى كه بهعنوان سفير سلامت خانوار فعاليت مى كنند زن

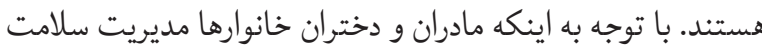


تأثير آموزشها بر افزايش و ماند عارى مباحث مطرحشده در ذهن

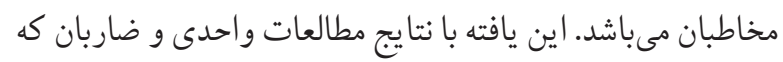

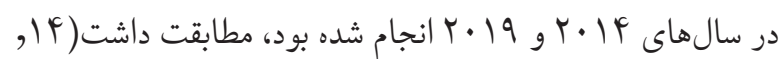
1 1). نكته ديكرى كه قابل بحث مى باشد تأثير آكاهى بر ادراك و نكرش افراد در انجام خودمراقبتى در ناخوشىهاى جزئى مى بـاشدي.

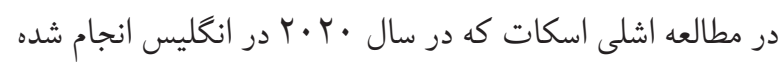

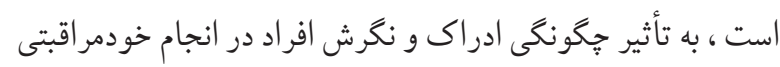

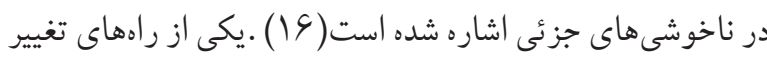

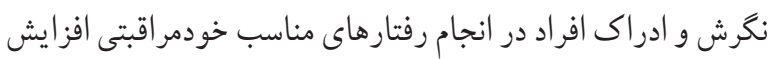

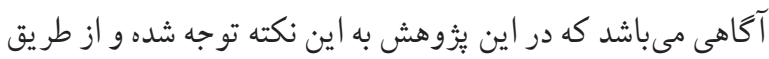

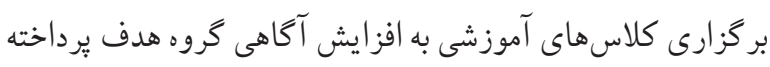

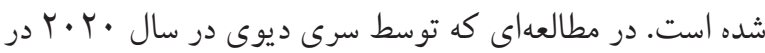
هند انجام شده است، بيانشده كه آموزش خودمراقبتى در بهبود وضعيت بيماران ديابتى و كاهش عوارض ديابت مؤثر مئد باشد. (IV)

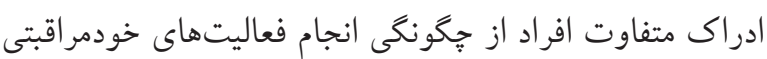
است و يكسان نمودن ادراك افراد بهمنظور انجام خودمراقبتى از

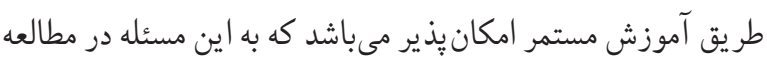

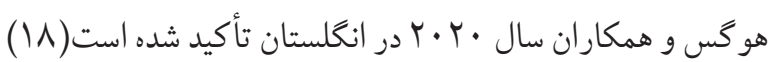
اطلاعات نشان مىدهد به غير از آكاهى در مورد مباحث ناخوشىهاى نوجوانان در بقيه موارد اختلاف معنىدار بين كروه اهيه

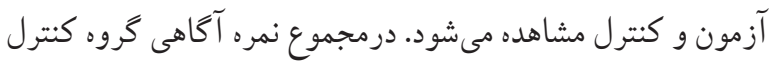

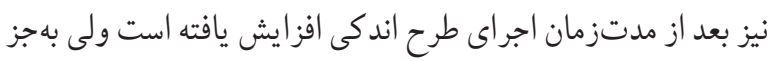

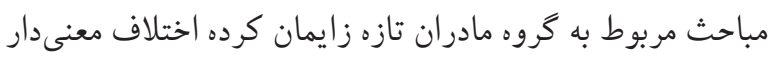

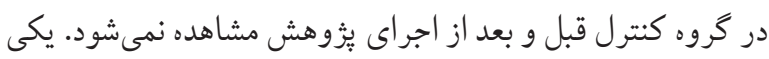

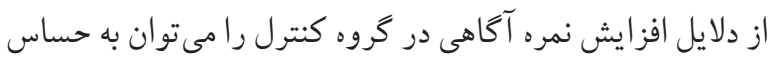
شدن اين افراد بعد از توزيع برسشنامه مرحله اول و تمايل ايشان

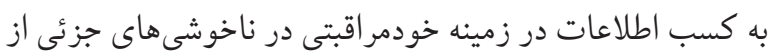
طريق منابع موجود نسبت داد.

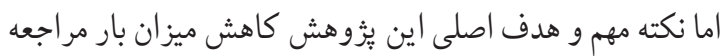
به بِزش به علت ناخوشىهاى جزئى در كروههاى سنى مختلف از
در گروه كنترل از نظر وضعيت اقتصادى اجتماعى ضعيف بودند

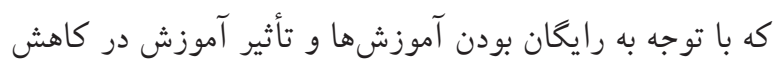
هز ينهاى مر اجعه به يز شك به علت ناخوشى هاى جزئى، اين برنامه،

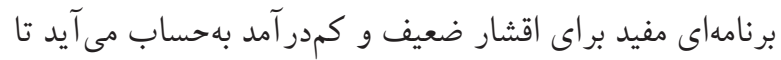
بتواند در حد امكان خودمراقبتى در ناخوشى هاى جزئى رأى را آموخته و از نظر مالى كمتر متضرر شوند. بر اساس كتاب خودمر اقبتى در

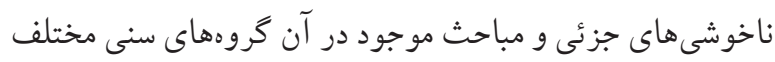

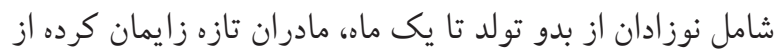

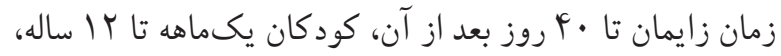

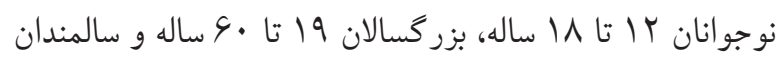

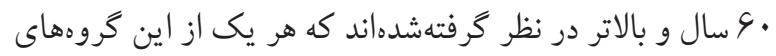

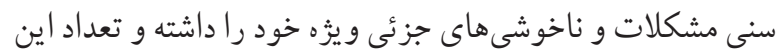
افراد در خانوارهايى كه سفير سلامت داشتند و همجنين خانوارهاى

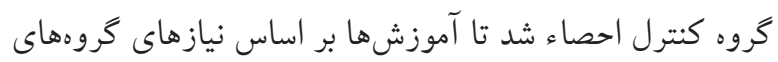

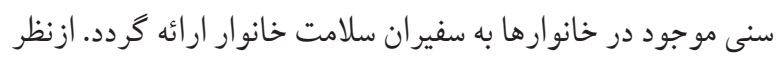
كروههاى سنى در گروه آزمون و كنترل بيشترين افراد در در سنين

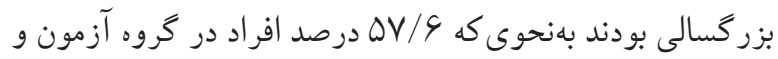

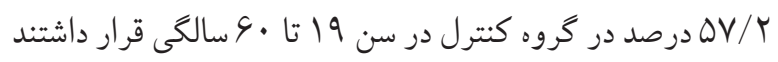

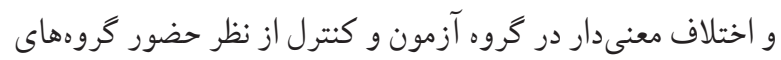
سنى در خانوارها وجود نداشت.

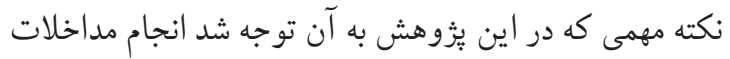

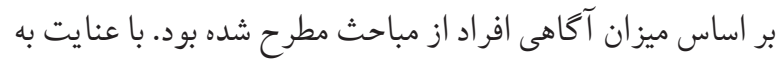

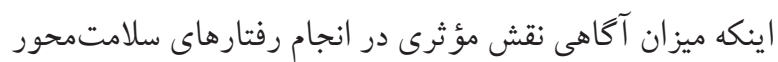

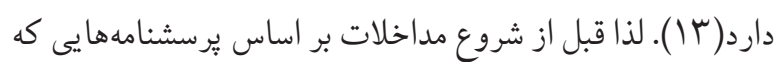

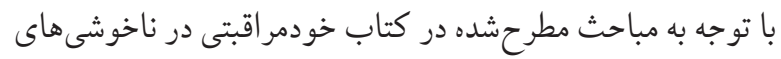
جزئى توسط دفتر آموزش و ارتقاى سلامت وزارت بهداشت، درمان و آموزش يزشكى تهيهشده بود ميزان آكاهى سفيران سلامت خانوار

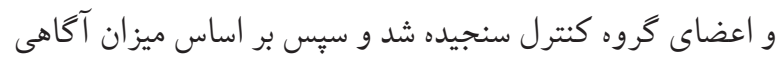
ايشان، مداخلات آموزشى مناسب طراحى گرديد. بر اساس اطلاعات

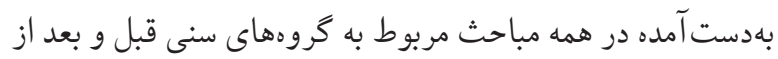

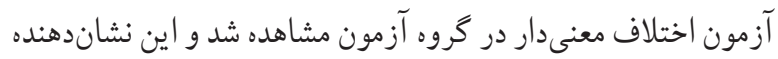


خطاى حافظه در ياسخ گويىى به سؤالات برسشنامه

بيشنهادات

برنامه تربيت سفيران سلامت خانوار و برنامه ملى خودمراقبتى از نظر كيفيت باكيفيت مطلوب فاصله بسيار دارد كه دلايل آن مطرح شد. با توجه به اينكه در اين يزوهش استانداردهاى برنامه با دقت انجام شد و آموزشها و يِيخيرىهاى دقيق به عمل آمد نتايج مطلوبى نيز حاصل گرديد. لذا ييشنهاد مىشود در اين برنامه بهجاى افزايش تصاعدى تعداد سفيران سلامت خانوار به كيفيت آموزش به اين گروه توجه بيشترى مبذول كردد.

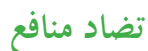
در اين مقاله هيج گونه تضاد منافعى وجود ندارد. تشكر و قدردانى اين مطالعه بركرفته از طرح تحقيقاتى مصوب دانشخاه علوم يزشكى

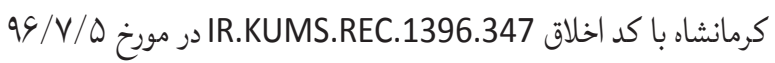
تائيد شده است و با كد IRCT20180619040153N1 مىباشد. نويسندگان مقاله از معاونت محترم تحقيقات و فناورى دانشگاه و مراقبين سلامت و روساى مراكز خدمات جامع سلامت و يايگاههاى سلامت مجرى طرح كمال تشكر و قدردانى را داريب.

\section{References}

Tarvonen-Schröder S, Kaljonen A, Laimi K. Utility of the World Health Organization disability assessment schedule and the World Health Organization minimal generic set of domains of functioning and health in spinal cord injury. Journal of rehabilitation medicine. 2019;51(1):40-6. https://doi.org/10.2340/16501977-2501

2. Ghoreishi M-S, Vahedian-Shahroodi $M$, Jafari $A$, Tehranid $H$. Self-care behaviors in patients with type 2 diabetes: Education intervention base on social cognitive theory. Diabetes \& Metabolic Syndrome: Clinical Research \& Reviews. 2019;13(3):2049-56. https://doi.org/10.1016/j.dsx.2019.04.045

3. Rahaei Z, Mehrjoyan N, Barzegr F, Anbari-Nogyni Z. Is Higher Health Literacy Associated with Better Self-Care in the Elderly? Journal of Health Literacy. 2020;5(3):26-35.

4. Newman S, Steed L, Mulligan K. Selfmanagement interventions for chronic illness. The Lancet. 2004;364(9444):1523-37.
طريق آموزش و تربيت سفيران سلامت خانوار و بر اساس كتاب خودمراقبتى در ناخوشىهاى جزئى بود. بر اساس اطلاعات حاصل از اين تحقيق تعداد بار مراجعه به يزشك در گروههاى سنى مختلف در گروه آزمون به نحو جشمخيرى بعد از آزمون كاهش يافته است و اختلاف معنى دار مشاهده مىشود. در گروه كنترل نيز در برخى كروههاى سنى از جمله نوزادان و مادران بار مراجعه كاهش يافته است و اختلاف معنىدار مشاهده مىشود، اما در كل بار مراجعه در كروه كنترل قبل و بعد از زمان اجراى طرح افزايش داشته است

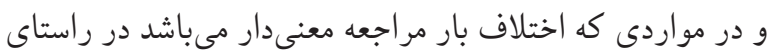
أز ايش بار مراجعه در گروه كنترل بوده است بهنحوى كه در گروه

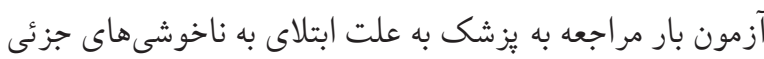

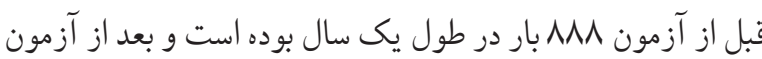
به اوبا بار در سال كاهش يافته است و اين در حالى است كه در كروه كنترل مراجعه به يزشك به علت ابتلا به ناخوشىهاى جزئى

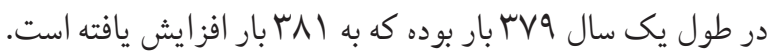
هر گند كه در بار مراجعه به يزشك قبل از آزمون نيز اختلاف معنىدار وجود داشته است ولى كاهش ميزان مراجعه به يزشك در گروه آزمون بسيار جشمگير است. در مطالعهاى كه سال I| • ب توسط نيلسن و همكاران در نروز به انجام رسيده، بيان شده است كه بيش از يكجهارم مراجعات به يزشكان به علت ابتلا به ناخوشىهاى جزئى است و به آموزش خودمراقبتى جهت كاهش ميزان مراجعه

$$
\text { به يزشك تأكيد نمودهاند.(19) }
$$

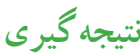

بر اساس اطلاعات بهدستآمده مىتوان نتيجه گرفت كه آموزش دقيق و مستمر خودمراقبتى در ناخوشىهاى جزئى و ارتباط مستقيم با مردم مىتواند نقش مهمى در كاهش ميزان مراجعه به يزشك و جلوگيرى از هدر رفتن وقت، هزينه و منابع و... داشته باشد. محلدوديت هاى مطالعه محدوديتهاى طرح عبارت بودند از: دركيرى اعضاى خانوار با بيمارىهاى غير واگير مزمن كه اهميت ناخوشىهاى جزئى را كمتر جلوه مىداد، عدم شركت سفيران سلامت در كلاسهاى آموزشى بهطور منظم و 
https://doi.org/10.1016/S0140-6736(04)17277-2

5. Fielding S, Porteous T, Ferguson J, Maskrey V, Blyth A, Paudyal $V$, et al. Estimating the burden of minor ailment consultations in general practices and emergency departments through retrospective review of routine data in North East Scotland. Family practice. 2015;32(2):165-72. https://doi.org/10.1093/fampra/cmv003

6. Mölstad S, Cars O, Struwe J. Strama-a Swedish working model for containment of antibiotic resistance. Eurosurveillance. 2008;13(46):19041. https://doi.org/10.2807/ese.13.46.19041-en

7. Rezaee N, Seraji M. The perceived supports for self-care in hemodialysis patients: a qualitative study. Iranian Journal of Health Education and Health Promotion. 2020;8(2):97-106. https://doi.org/10.29252/ijhehp.8.2.97

8. Gustafsson S, Vikman I, Axelsson K, Sävenstedt S. Self-care for minor illness. Primary health care research \& development. 2015;16(1):71-8. https://doi.org/10.1017/S1463423613000522

9. Gustafsson S, Martinsson J, Wälivaara BM, Vikman I, Sävenstedt S. Influence of self-care advice on patient satisfaction and healthcare utilization. Journal of advanced nursing. 2016;72(8):1789-99. https://doi.org/10.1111/jan.12950

10. Kinnersley P, Anderson E, Parry K, Clement J, Archard $L$, Turton $P$, et al. Randomised controlled trial of nurse practitioner versus general practitioner care for patients requesting "same day" consultations in primary care. Bmj. 2000;320(7241):1043-8. https://doi.org/10.1136/bmj.320.7241.1043

11. Porteous T, Ryan M, Bond CM, Hannaford P. Preferences for self-care or professional advice for minor illness: a discrete choice experiment. British Journal of General Practice. 2006;56(533):911-7.

12. Paudyal V, Hansford D, Cunningham S, Stewart D. Pharmacy assisted patient self care of minor ailments: a chronological review of UK health policy documents and key events 1997-2010. Health policy. 2011;101(3):253-9. https://doi.org/10.1016/j.healthpol.2011.05.010

13. Robbins TW, Vaghi MM, Banca P. Obsessivecompulsive disorder: puzzles and prospects. Neuron. 2019;102(1):27-47. https://doi.org/10.1016/j.neuron.2019.01.046

14. Mohammad Vahedi R. Assess knowledge, attitudes and skills of health Ambassadors in Maragheh in 1396: Tabriz University of Medical Sciences, School of Health; 2019.

15. Zareban I, Niknami S, Hidarnia A, Rakhshani F, Shamsi $M$, Karimy $M$. Effective intervention of self-care on glycaemia control in patients with type 2 diabetes. Iranian Red Crescent Medical Journal. 2014;16(12). https://doi.org/10.5812/ircmj.8311

16. Scott A, Jones C. An exploration of the attitudes and perceptions of the UK public towards self-care for minor ailments. British Journal of Nursing. 2020;29(1):44-9. https://doi.org/10.12968/bjon.2020.29.1.44

17. Sreedevi K. A study to assess the effectiveness of structured Teaching Programme on self-care management of patients with type 2 Diabetes mellitus and Evaluation of prognosis in selected Hospitals. Asian Journal of Nursing Education and Research. 2020;10(4):427-31.

18. Hughes J, Sharma R, Brough N, Majumdar A, Fisher P. 'The care that you give to yourself': a qualitative study exploring patients' perceptions of self-care. European Journal of Integrative Medicine. 2020:101246. https://doi.org/10.1016/j.eujim.2020.101246

19. Welle-Nilsen LK, Morken T, Hunskaar S, Granas AG. Minor ailments in out-of-hours primary care: an observational study. Scandinavian journal of primary health care. 2011;29(1):39-44. https://doi.org/10.3109/02813432.2010.545209 